\title{
Construction and Characterization of a Bacterial Artificial Chromosome Library for the Hexaploid Wheat Line 92R137
}

\author{
Qingdong Zeng, ${ }^{1}$ Fengping Yuan, ${ }^{2} \mathrm{Xin} \mathrm{Xu},{ }^{2} \mathrm{Xue} \mathrm{Shi},{ }^{2} \mathrm{Xiaojun} \mathrm{Nie},{ }^{2}$ \\ Hua Zhuang, ${ }^{1}$ Xianming Chen, ${ }^{3}$ Zhonghua Wang, ${ }^{2}$ Xiaojie Wang, ${ }^{1}$ Lili Huang, \\ Dejun Han, ${ }^{2}$ and Zhensheng Kang ${ }^{1}$ \\ ${ }^{1}$ State Key Laboratory of Crop Stress Biology for Arid Areas and College of Plant Protection, Northwest A\&F University, Yangling, \\ Shaanxi 712100, China \\ ${ }^{2}$ State Key Laboratory of Crop Stress Biology for Arid Areas and College of Agronomy, Northwest A\&F University, Yangling, \\ Shaanxi 712100, China \\ ${ }^{3}$ Wheat Genetics, Quality, Physiology, and Disease Research Unit, Agricultural Research Service, \\ United States Department of Agriculture, and Department of Plant Pathology, Washington State University, Pullman, \\ WA 99164-6430, USA \\ Correspondence should be addressed to Zhensheng Kang; kangzs@nwsuaf.edu.cn
}

Received 28 January 2014; Revised 26 March 2014; Accepted 18 April 2014; Published 5 May 2014

Academic Editor: Guihua H. Bai

Copyright (c) 2014 Qingdong Zeng et al. This is an open access article distributed under the Creative Commons Attribution License, which permits unrestricted use, distribution, and reproduction in any medium, provided the original work is properly cited.

\begin{abstract}
For map-based cloning of genes conferring important traits in the hexaploid wheat line 92R137, a bacterial artificial chromosome (BAC) library, including two sublibraries, was constructed using the genomic DNA of 92R137 digested with restriction enzymes HindIII and BamHI. The BAC library was composed of total 765,696 clones, of which 390,144 were from the HindIII digestion and 375,552 from the BamHI digestion. Through pulsed-field gel electrophoresis (PFGE) analysis of 453 clones randomly selected from the HindIII sublibrary and 573 clones from the BamHI sublibrary, the average insert sizes were estimated as 129 and $113 \mathrm{~kb}$, respectively. Thus, the HindIII sublibrary was estimated to have a 3.01-fold coverage and the BamHI sublibrary a 2.53-fold coverage based on the estimated hexaploid wheat genome size of 16,700 Mb. The 765,696 clones were arrayed in 1,994 384-well plates. All clones were also arranged into plate pools and further arranged into 5-dimensional (5D) pools. The probability of identifying a clone corresponding to any wheat DNA sequence (such as gene Yr26 for stripe rust resistance) from the library was estimated to be more than $99.6 \%$. Through polymerase chain reaction screening the 5D pools with Xwe173, a marker tightly linked to Yr26, six BAC clones were successfully obtained. These results demonstrate that the BAC library is a valuable genomic resource for positional cloning of Yr26 and other genes of interest.
\end{abstract}

\section{Introduction}

Providing about $20 \%$ of calories consumed by humans, wheat (Triticum aestivum L.) feeds $35 \%$ of the world's population as one primary food $[1,2]$. Wheat stripe (yellow) rust, caused by Puccinia striiformis Westend. f. sp. tritici Erikss. (Pst), is one of the most destructive diseases worldwide $[3,4]$. China is considered to be the largest individual region suffering stripe rust damage in the world, and its annual wheat yield loss caused by the disease is about one million metric tons on average [5]. Growing resistant cultivars is considered to be the most economically effective and environmentally safe measure for control of stripe rust [6,7]. For developing resistant cultivars, wheat germplasm with effective resistance and genes conferring the resistance should be identified.

92R137 is a T. aestivum and Haynaldia villosa 6VS/6AL translocation line of hexaploid wheat developed by the Cytogenetics Institute of Nanjing Agricultural University [8]. The line possesses a cloned gene, Pm21, on the translocated chromosomal segment $6 \mathrm{VS}$ for resistance to powdery mildew, 
caused by Blumeria graminis f. sp. tritici (Bgt) [9]. It has a stripe rust resistance gene, $\operatorname{Yr} 26$, which is effective against predominant races of Pst in China [8, 10-13]. Although Yr26 is identified as susceptible to a new virulent pathotype, it can provide good protection of crops from the Pst population when combined with other resistance genes, because the virulent pathotype has a narrow spectrum of virulence [14]. Because 92R137 has resistance to both stripe rust and powdery mildew, the two most important wheat diseases in China, the line has been widely used in wheat breeding programs in China [8]. Cloning Yr26 can contribute to the understanding of molecular mechanisms of stripe rust resistance and provide basis for wisely using the gene and other genes to achieve long lasting and high level resistances to stripe rust.

A high-resolution map has been developed for Yr26 in a population developed with 92R137 [14]. Among a large number of markers linked with Yr26, codominant marker Xwe173, which was developed from wheat EST BF474347 [8], was found to be only $1.4 \mathrm{cM}$ away and appeared to be reliable for marker-assisted detection of the gene [15]. Because Yr26 is mapped close to the centromere of chromosome $1 \mathrm{~B}$ [8], it is difficult to identify closer markers. Although we are currently using a much larger population (composed of nearly 10,000 $\mathrm{F}_{2}$ individuals) for identifying closer markers, a bacterial artificial chromosome library (BAC) developed from the resistant wheat line should speed up the process of cloning Yr26.

In Triticeae, seven genes for resistance to rusts are cloned, including $L r 1$ [16], Lr10 [17], and Lr21 [18] for resistance to leaf rust; Sr33 [19] and Sr35 [20] for resistance to stem rust; Yr36 [1] for resistance to stripe rust; and Lr34/Yr18 conferring resistance to both leaf rust and stripe rust [21]. These molecularly very diverse genes were cloned all using the map-based cloning approach. Therefore, we have taken the approach for cloning Yr26 in 92R137. This approach requires establishing physical maps using a large insert library. Among the different kinds of libraries, a BAC library is a preferred system over other large insert libraries for its advantage of easy operation, high stability, and low chimerism [22].

Although several protocols of BAC library construction [22-28] and BAC libraries for tetraploid wheat and hexaploid wheat [29-35] have been published, research progress for development of large insertion libraries for a large genome species is still limited. Particularly, hexaploid wheat has a very large genome of $16.7 \mathrm{~Gb}$ [36]. In various reports, different methods were adopted to improve transformation efficiency and quality, such as multiple selection to remove small DNA molecules [37], electroelution means to recover size-selected DNA from agarose gel [24], and using TAE instead of TBE buffer in electroelution $[26,38]$. In the present study, we tried to integrate almost all these modified methods to construct a high quality BAC library for 92R137, aimed at cloning Yr26. To improve genome representation and reduce the gaps between $\mathrm{BAC}$ contigs resulting from uneven distribution of restriction sites [39], HindIII and BamHI were used separately to obtain BAC clones. To speed up screening the BAC for 92R137, a new 5D clone pooling scheme [40] was adopted and proven to be more efficient.

\section{Materials and Methods}

2.1. Plant Material and HMW DNA Preparation. Spring wheat 92R137, kindly provided by Professor Peidu Chen at the Nanjing Agricultural University, was used for BAC library construction. Seeds were sown in pots filled with soil mixture and plants were grown in dark at room temperature. When they grew up to $10 \mathrm{~cm}$ long, seedlings were harvested for DNA extraction.

Twenty-five gram leaf tissue was ground into fine powder in liquid nitrogen following the slightly modified procedure described by Luo and Wing [28] to release their intact nuclei. The nuclei were isolated and purified four times with ice-cold NIBM (10 mM Tris- $\mathrm{HCl}$ with a $\mathrm{pH}$ of $8.0,10 \mathrm{mM}$ EDTA with a $\mathrm{pH}$ of $8.0,100 \mathrm{mM} \mathrm{KCl}, 0.5 \mathrm{M}$ sucrose, $4 \mathrm{mM}$ spermidine, $1 \mathrm{mM}$ spermine with $10 \%$ Triton $\mathrm{X}-100$, and $0.1 \% \beta$-mercaptoethanol) at $10 \mathrm{~mL} / 1 \mathrm{~g}$ tissue and centrifuged at a force set to $1800 \mathrm{~g}$. The obtained pellet was gently resuspended in approx. $1 \mathrm{~mL}$ NIB $(10 \mathrm{mM}$ Tris- $\mathrm{HCl}, \mathrm{pH} 8.0$; $10 \mathrm{mM}$ EDTA, $\mathrm{pH}$ of $8.0 ; 100 \mathrm{mM} \mathrm{KCl} ; 0.5 \mathrm{M}$ sucrose; $4 \mathrm{mM}$ spermidine, and $1 \mathrm{mM}$ spermine with $10 \%$ Triton $\mathrm{X}-100$ ). At the equal volume, $1 \%(\mathrm{w} / \mathrm{v})$ low melting temperature (LMP) agarose (Amresco, Solon, OH, USA) dissolved in NIB was added into the suspension and the mixture was poured into a $100 \mu \mathrm{L}$ Plug Mold (Bio-Rad, Hercules, CA, USA). After adding lysis buffer $0.5 \mathrm{~mol} / \mathrm{L}$ EDTA with a $\mathrm{pH}$ of 9.0 , $1 \%(\mathrm{w} / \mathrm{v}) \mathrm{N}$-lauroylsarcosine and proteinase $\mathrm{K}$ at $1 \mathrm{mg} / \mathrm{mL}$ (Amresco), the plugs were rotated in an incubator at $50^{\circ} \mathrm{C}$ for about $48 \mathrm{~h}$, and at $24 \mathrm{~h}$, the buffer was changed with fresh buffer. Then, the agarose plugs were rinsed twice with icecold $\mathrm{T}_{10} \mathrm{E}_{10}$ buffer $(10 \mathrm{mmol} / \mathrm{L}$ Tris- $\mathrm{HCl}$ with a $\mathrm{pH}$ of 8.0 , $10 \mathrm{mmol} / \mathrm{L}$ EDTA with a $\mathrm{pH}$ of 8.0 ) containing $1 \mathrm{mmol} / \mathrm{L}$ phenylmethylsulphonyl fluoride (Sigma, St Louis, MO, USA) and twice with ice-cold TE buffer, 1 hour each rinse. Then, the plugs were stored in TE buffer $\left(\mathrm{pH} \mathrm{8.0)}\right.$ at $4^{\circ} \mathrm{C}$ for future use.

2.2. Restriction Digestion and DNA Fragment Size Selection. To determine the optimum conditions for the highest percentage of fragments between 120 and $242.5 \mathrm{~kb}$, a series of eight partial digests were performed. One half of the DNA plug was chopped into fine pieces as one treatment and equilibrated with $45 \mu \mathrm{L}$ of restriction enzyme buffer for 30 minutes. $5 \mu \mathrm{L}$ enzyme diluents with $0,0.4,0.8,1.2,1.6,2.0,2.4$, and $10 \mathrm{U}$ Bam HI or HindIII (New England Biolabs, Ipswich, MA, USA) were added into the treatment contained in microcentrifuge tubes and placed on ice for 30 minutes. Then, the microcentrifuge tubes were incubated in $37^{\circ} \mathrm{C}$ water bath for 30 minutes for digestion. After adding $10 \mu \mathrm{L} 0.5 \mathrm{~mol} / \mathrm{L}$ EDTA ( $\mathrm{pH} 8.0$ ), the tubes were incubated on ice for at least $10 \mathrm{~min}$ to stop digestion.

The plug pieces were separated in a $1 \%$ agarose gel in $0.5 \mathrm{x}$ TBE using a CHEF DR-III System (Bio-Rad) at $6 \mathrm{~V} / \mathrm{cm}, 1-50 \mathrm{~s}$ switch times, linear ramp, $120^{\circ}$ angle at $14^{\circ} \mathrm{C}$ for $18 \mathrm{~h}$. Once the optimal digestion condition for one batch of plugs to produce fragments between 120 and $242.5 \mathrm{~kb}$ was identified, the partial digestions of 6 plugs were performed under the optimal digestion condition. DNA fragments with sizes ranging from 120 to $242.5 \mathrm{~kb}$ were excised (corresponding to $120-180$ and 
$180-242.5 \mathrm{~kb}$ measured by a ruler) and reloaded onto new $1 \%$ agarose gel in $0.5 \mathrm{x}$ TBE and run at $6 \mathrm{~V} / \mathrm{cm} 3-5 \mathrm{~s}$ switch times, linear ramp, $120^{\circ}$ angle at $14^{\circ} \mathrm{C}$ for $18 \mathrm{~h}$ to select them by size once again [27]. After the agarose slices containing fragments larger than $120 \mathrm{~kb}$ were recovered, the DNA was electroeluted for $3.5 \mathrm{~h}$ at $4.5 \mathrm{~V} / \mathrm{cm}$ in electrophoresis cell (JY-SP-C, JUNYI, Beijing). The polarities of electrophoresis cell were reversed at $4^{\circ} \mathrm{C}$ for $1 \mathrm{~min}$ [24]. The concentrations of the electroeluted DNA were measured by agarose gel electrophoresis with the $\lambda$ DNA marker.

2.3. Vectors. The library construction vectors were $8.1 \mathrm{~kb}$ CopyControl pCC1BAC HindIII Cloning-Ready Vectors and 8.1 kb CopyControl pCC1BAC BamHI Cloning-Ready Vectors (Epicentre, Madison, WI, USA). Both vectors allow for the LacZ based blue-white selections of recombinant clones and the selection of chloramphenicol resistance as an antibiotic selectable markers.

2.4. Ligation and Bacterial Transformation. The ligations were individually carried out in a $100 \mu \mathrm{L}$ reaction solution according to the manufacturer's instructions. First, 25 ng vectors, about 100 ng electroeluted HMW DNA and appropriate $\mathrm{ddH}_{2} \mathrm{O}$, were mixed to form an $84 \mu \mathrm{L}$ solution and incubated at $65^{\circ} \mathrm{C}$ for $10 \mathrm{~min}$. The solution was cooled to $4^{\circ} \mathrm{C}$ and added with $10 \mu \mathrm{L} 10 \mathrm{x}$ Fast-Link ligation buffer, $1 \mu \mathrm{L} 100$ mM ATP, and $2 \mu \mathrm{L}$ Fast-Link DNA ligase. The ligation solutions were incubated at $16^{\circ} \mathrm{C}$ for $16 \mathrm{~h}$. Finally, the reaction solutions were heated to $65^{\circ} \mathrm{C}$ for $15 \mathrm{~min}$ to inactivate Fast-Link DNA ligase and desalted with an agarose cone on ice for $1.5 \mathrm{~h}$ [41].

The transformation of the ligation product into TransforMax EPI300 Electrocompetent E. coli cells (Epicentre) was carried out in $0.1 \mathrm{~cm}$ cuvettes by electroporation using a MicroPulser Electroporation Apparatus (Bio-Rad) at a $1.6 \mathrm{kV}(E=16 \mathrm{kV} / \mathrm{cm})$ [38]. One microliter of the ligation product and $20 \mu \mathrm{L}$ of the transformed EPI300 cells were gently blended in a wide-bore pipette tip for electroporation. Immediately, the cells were transferred into $1 \mathrm{~mL}$ SOC medium [28] and incubated at $37^{\circ} \mathrm{C}$ for $1 \mathrm{~h}$ while shaken at $200 \mathrm{rpm}$ [22]. The cells were placed on LB medium containing $12.5 \mu \mathrm{g} / \mathrm{mL}$ chloramphenicol, $90 \mu \mathrm{g} / \mathrm{mL}$ $\mathrm{X}-\mathrm{Gal}$, and $90 \mu \mathrm{g} / \mathrm{mL}$ IPTG [27] and incubated at $37^{\circ} \mathrm{C}$ for $20 \mathrm{~h}$.

2.5. Isolation and Determination of Insert DNA. The recombinant clone number per microliter of the ligation product was determined by counting white colonies. If the number was above 500 and blue colonies were less than 20\% [27], 2024 white colonies were randomly sampled from each ligation and allowed to grow in $4 \mathrm{~mL} \mathrm{LB}$ containing $12.5 \mu \mathrm{g} / \mathrm{mL}$ chloramphenicol $37^{\circ} \mathrm{C}$ for $16 \mathrm{~h}$ while shaken at $200 \mathrm{rpm}$. Plasmid DNA isolation was conducted following a modified alkaline lysis protocol [27]. The plasmid DNA was digested with $5 \mathrm{U}$ of Not (Fermentas) at $37^{\circ} \mathrm{C}$ for $4 \mathrm{~h}$ and loaded onto $1 \%$ agarose in $0.5 \mathrm{x}$ TBE CHEF gel $(6 \mathrm{~V} / \mathrm{cm}, 5-15 \mathrm{~s}$ pulse time for $16 \mathrm{~h}$ at $14^{\circ} \mathrm{C}$ ) to determine the insert size. $\lambda$ PFG Marker
(New England Biolabs) along with the Quantity One (BioRad, V4.62) was used for molecular weight determination.

2.6. Picking and Storing BAC Clones. If the test colonies met the requirements in average insert size $(>100 \mathrm{~kb})$ and empty vector rate $(<5 \%)$, all ligated DNAs were transformed into EPI300 competent cells. Individual white colonies were manually picked with sterilized toothpicks and placed in wells of 384-well plates containing freezing media [28]. The plates carrying white colonies were incubated at $37^{\circ} \mathrm{C}$ for $20 \mathrm{~h}$, and a duplicate copy of the primary BAC library was made by inoculation of clones from the primary source plates to new plates with a hand-holding replicator, and the new plates were cultured under the same conditions. The primary and secondary copies were stored at $-80^{\circ} \mathrm{C}$.

2.7. Testing Chloroplast Contamination. To test the chloroplast contamination of the BAC library, a set of PCR primers was designed for three selected chloroplast genes. The first gene encodes a NADH dehydrogenase, and the primer pair of $5 \mathrm{ndh}\left(3^{\prime}\right.$-GGGTAGAGGTAGAAACTATC$\left.5^{\prime}\right)$ and 3 ndh ( $3^{\prime}$-CGCTTCTGAATTGATCTCATCC- $\left.5^{\prime}\right)$ was used to amplify a $1.4 \mathrm{~kb}$ fragment. The second gene encodes a Photosystem II protein, and the primer pair of 5psb ( $3^{\prime}$-GGAAGCTGCATCTGTTGATG-5') and 3psb (3' AGGGAAGTTGTGAGCATTACG- $5^{\prime}$ ) was used to amplify an 800 bp fragment. The third gene encodes the Ribulose-1,5bisphosphate carboxylase large subunit, and the primer pair $5 \mathrm{rbcL}\left(3^{\prime}\right.$-CTGATACTTGGCAGCATTCC-5') and $3 \mathrm{rbcL}$ $\left(3^{\prime}\right.$-CGATTAGCTGCTGCACCAG- $\left.5^{\prime}\right)$ was used to amplify a $1.2 \mathrm{~kb}$ fragment [22]. The genomic DNA of 92R137 was used as the positive control.

2.8. Pooling BAC Clones. The improved 5D clone pooling strategy [40] was used to make pools of BAC clones. The $5 \mathrm{D}$ pools contained pools of the $3 \mathrm{D}$ traditional grid design row-pools (RP), column-pools (CP), and plate-pools (PP) and $2 \mathrm{D}$ super pools the row super-pools (RSP) and column super-pools (CSP) of the plate-pools. To obtain a plate-pool, BAC clones in the wells of each 384-well plate were dipped into $30 \mathrm{~mL}$ LB broth containing $12.5 \mathrm{mg} / \mathrm{L}$ chloramphenicol with the 384-pin replicator to inoculate the clones on a LB broth. After growing overnight, the clone cells were precipitated by centrifugation and resuspended with $1 \mathrm{~mL}$ $10 \%$ glycerol and stored at $-80^{\circ} \mathrm{C}$ for future use. In such a way, a total of 1,994 plate pools were produced. Plasmid DNA was isolated from $100 \mu \mathrm{L}$ cell culture of each pool following the standard alkaline lysis protocol. The plate-pool DNA was dissolved in $1 \mathrm{x}$ TE buffer and the concentration was measured with a Nanodrop 2000 spectrophotometer (Nano-drop Technologies, Wilmington, DE) at a wavelength of $260 \mathrm{~nm}$.

To construct super pools, the 1,994 plate pools were divided into 20 primary BAC groups each of which contained 100 BAC plates (arranged in a grid consisting of 10 rows and 10 columns). 


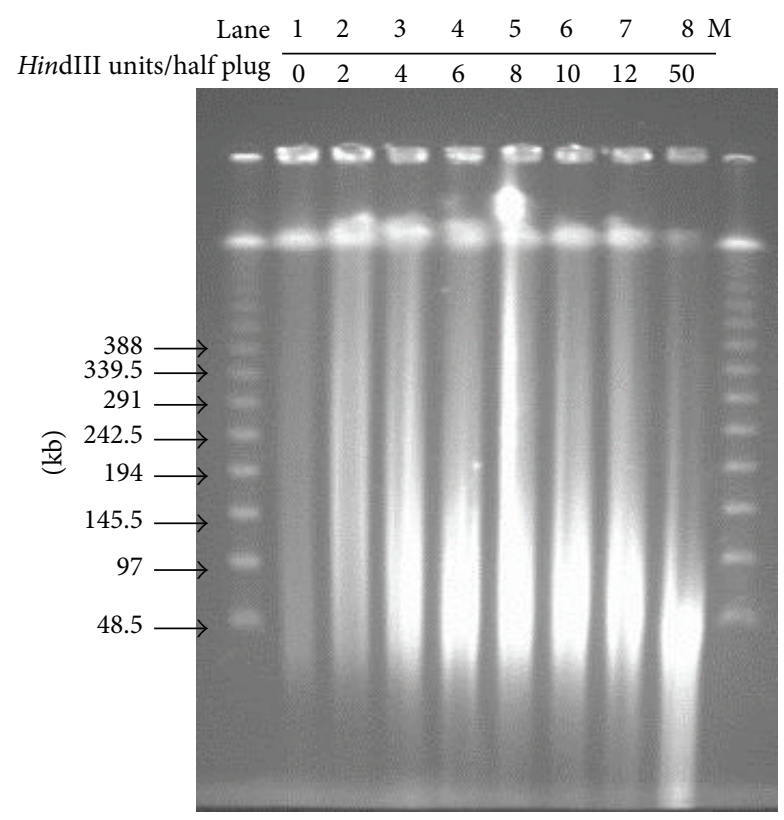

(a)

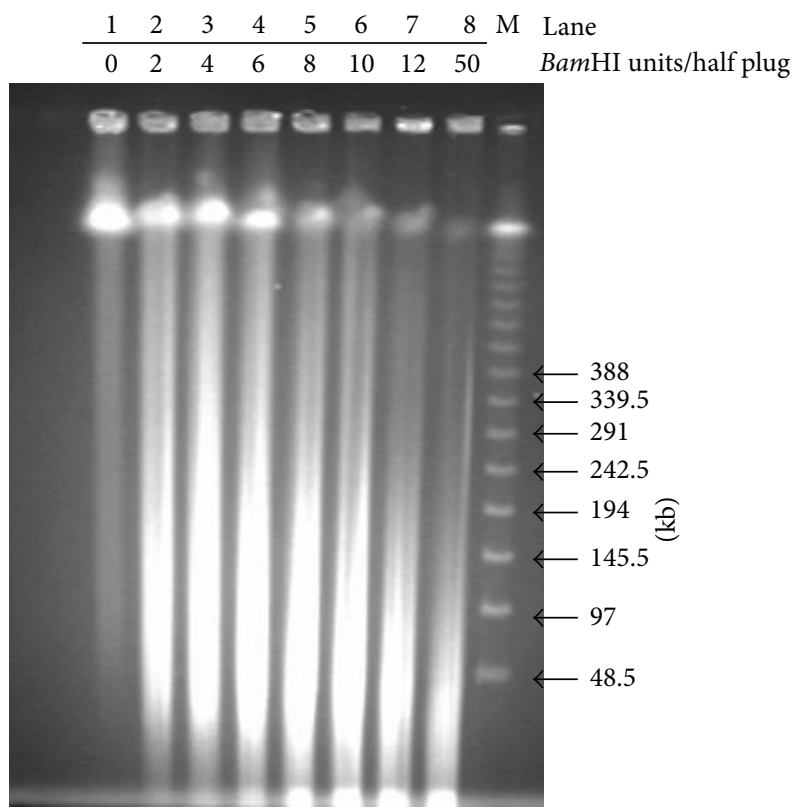

(b)

FIGURE 1: Partial digestion of DNA in half plugs. Lanes 1-8 contain DNA samples digested with restriction enzyme at the increasingly higher concentrations. (a) Partial digestions of half DNA plugs with serial dilutions of HindIII at $37^{\circ} \mathrm{C}$ for $30 \mathrm{~min}$. (b) Partial digestions of half DNA plugs with serial dilutions of $\mathrm{BamHI}$ at $37^{\circ} \mathrm{C}$ for $30 \mathrm{~min}$. Plug pieces were separated on $1 \%$ agarose gel in $0.5 \mathrm{x}$ TBE and run in the CHEF DR-III System (Bio-Rad) at $6 \mathrm{~V} / \mathrm{cm}, 1-50 \mathrm{~s}$ switch time, linear ramp, $120^{\circ}$ angle at $14^{\circ} \mathrm{C}$ for $18 \mathrm{~h}$. M: the $\lambda$ PFG marker.

Same amounts of the DNAs of the plate-pools in one row or column were pooled to produce a row (column) superpool. The $2 \mathrm{D}$ super-pool grid of each primary group consisted of 20 super-pools (each containing 3840 clones). The DNAs of the super-pools were diluted to $5 \mathrm{ng} / \mu \mathrm{L}$ with deionizeddistilled water and employed as the PCR screening templates.

For each plate, 40 clone-pools (16 row-pools and 24 column-pools) were generated by blending $1 \mu \mathrm{L}$ cell culture in each row (column) with $3 \mathrm{~mL} \mathrm{LB}$ broth containing $12.5 \mathrm{mg} / \mathrm{L}$ of chloramphenicol. After the cell cultures grew overnight, DNAs were isolated following the standard alkaline lysis protocol and dissolved into 1x TE buffer. The concentrations of the DNAs were measured with a Nanodrop 2000 spectrophotometer and they were diluted to have a concentration of $5 \mathrm{ng} / \mu \mathrm{L}$ with deionized-distilled water and used as a PCR template for screening.

2.9. Screening BAC Library with Yr26 Linked Markers. Xwe173, a STS marker linked with Yr26 derived from wheat EST BF474347 [8], was used in screening the BAC library. Four hundred super pools of 20 groups were PCR screened. The primers Xwe173F ( $3^{\prime}$-GGGACAAGGGGAGTTGAAGC$\left.5^{\prime}\right)$ and Xwe173R ( $3^{\prime}$-GAGAGTTCCAAGCAGAACAC-5') were synthesized by Sangon Biotech Co., Ltd. (Shanghai, China). The PCR was performed in $15 \mu \mathrm{L}$ reaction mix containing $1 \mathrm{x}$ PCR buffer $\left(\mathrm{MgCl}_{2}\right.$-free, Fermentas, Canada), $2 \mathrm{mM} \mathrm{MgCl}_{2}$ (Fermentas, Canada), $0.2 \mathrm{mM}$ dNTPs (Roche, German), 0.75 unit Taq DNA polymerase (Fermentas, Canada), and $0.6 \mu \mathrm{M}$ each primer. The PCR amplification was performed in a Bio-Rad S1000 Thermal Cycler with 96well fast reaction module. The amplification cycling profile was $94^{\circ} \mathrm{C}$ for $4 \mathrm{~min}, 35$ cycles each consisting of $94^{\circ} \mathrm{C}$ for $30 \mathrm{~s}, 60^{\circ} \mathrm{C}$ for $1 \mathrm{~min}, 72^{\circ} \mathrm{C}$ for $1 \mathrm{~min}$, and extension at $72^{\circ} \mathrm{C}$ for $10 \mathrm{~min}$. The genomic DNA of 92R137 was used as the positive control. After amplification, $3 \mu \mathrm{L} 6 \mathrm{x}$ loading dye (Fermentas, Pittsburgh, PA, USA) was added to the PCR product. Then, $8 \mu \mathrm{L}$ of the PCR product and loading buffer mixture for each sample was loaded onto $2 \%$ agarose gel in $1 \mathrm{x}$ TAE buffer and electrophoresed at $5 \mathrm{~V} / \mathrm{cm}$ for about $30 \mathrm{~min}$. The gel was stained with $0.5 \mu \mathrm{g} / \mathrm{mL}$ ethidium bromide for $20 \mathrm{~min}$ and visualized under UV light using Molecular Imager Gel Doc $\mathrm{XR}+$ System (Bio-Rad, USA).

After the plates containing positive BAC clones were identified, 40 clone-pools (16 RP and $24 \mathrm{CP}$ ) of each selected plate were further screened to identify individual positive $\mathrm{BAC}$ clones under the same PCR reaction condition as for the super pools. The positive BAC clones were individually confirmed under the same PCR conditions. All of the PCR amplifications were repeated three times.

\section{Results}

3.1. Pilot Partial Digestions and Selection of Large DNA Fragments. The different enzyme concentrations under the same incubation times were used in the study. The undigested DNA (Figures 1(a) and 1(b), Lane 1) appeared to have a mean length $>600 \mathrm{~kb}$ and almost no disintegration, indicating that the high molecular weight (HMW) DNAs had a good integrity. After an additional amount of the enzyme was added, the DNAs were fully digested ( $<50 \mathrm{~kb}$ ) (Figures 1 (a) and $1(\mathrm{~b})$, Lane 8 ), indicating that the DNAs in the plugs were pure 


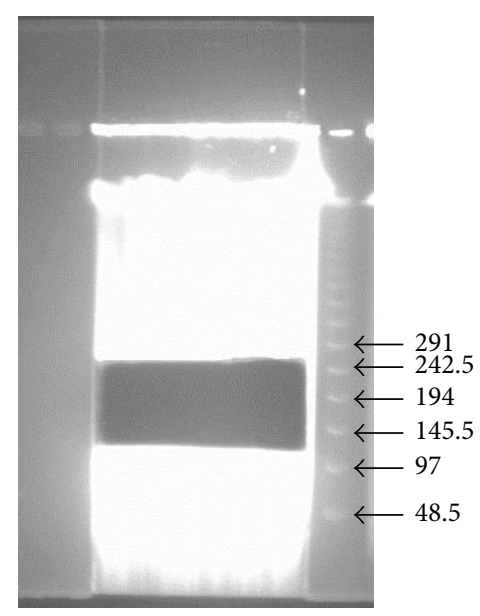

(a)

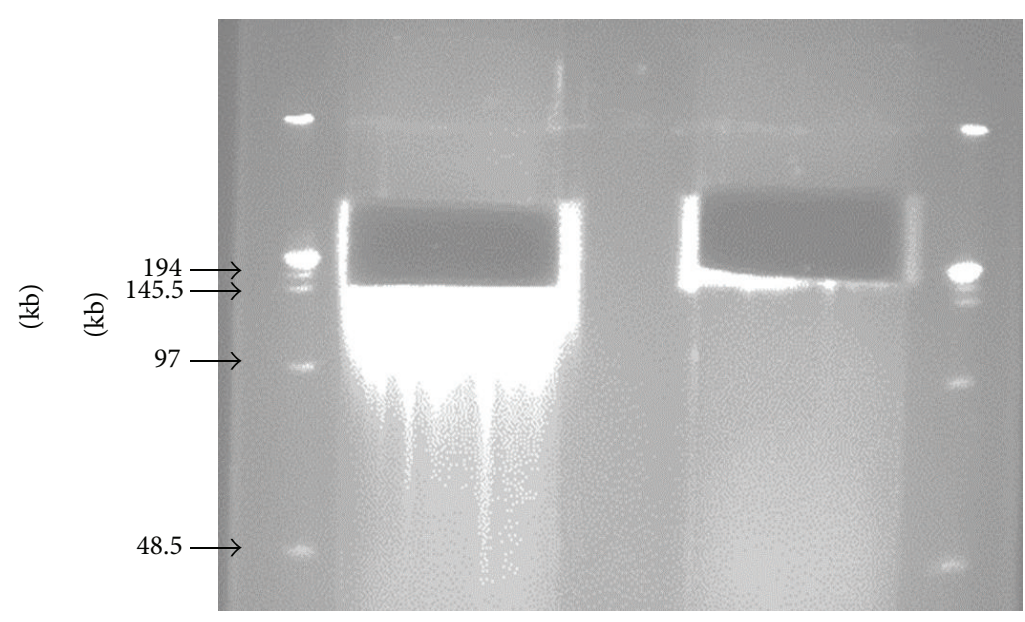

(b)

FIGURE 2: Size selections of the partially digested products of genomic DNA of wheat line 92R137. (a) The first size selection of the partially digested products of genomic DNA. Plug pieces were separated on $1 \%$ agarose gel in $0.5 \mathrm{x}$ TBE buffer and run in a CHEF DR-III System (Bio$\mathrm{Rad}$ ) at $6 \mathrm{~V} / \mathrm{cm}, 1-50 \mathrm{~s}$ switch time, linear ramp, $120^{\circ}$ angle at $14^{\circ} \mathrm{C}$ for $18 \mathrm{~h}$. (b) The second size selection of the partially digested products of genomic DNA. The first size selected fractions were separated on $1 \%$ agarose gel in $0.5 \mathrm{x}$ TBE buffer and run at $6 \mathrm{~V} / \mathrm{cm} 3-5 \mathrm{~s}$ switch time, linear ramp, $120^{\circ}$ angle at $14^{\circ} \mathrm{C}$ for $18 \mathrm{~h}$. M: the $\lambda$ PFG marker.

enough to digest. Because fragments between $120 \mathrm{~kb}$ and $242.5 \mathrm{~kb}$ were desirable, the reaction conditions adopted in the lane which appeared to contain the highest amounts of fragments within this size range were used in the large-scale restriction digestion (Figures 1(a) and 1(b), Lane 3).

Once the reaction condition for producing fragments between 120 and $242.5 \mathrm{~kb}$ was determined, a mass digestion using several plugs was performed to produce insert DNA for the construction of a BAC library. After electrophoresis, the first size selection of the partially digested products of genomic DNA of 92R137 was carried out to recover gel fraction containing $120-242.5 \mathrm{~kb}$ fragments (Figure 2(a)). The second size selection was performed using the first size-selected fractions cut from the center part of the gel fractions corresponding to $120-180 \mathrm{~kb}$ fragments and $180-$ $242.5 \mathrm{~kb}$ fragments. After the second electrophoresis, the gel fractions containing DNA fragments larger than $150 \mathrm{~kb}$ were located with a ruler and recovered from the gel (Figure 2(b)). These gel fractions were immediately used in cloning.

\subsection{BAC Library Construction and Characterization. After} electroelution, ligation, and transformation, two BAC constructs from the genomic DNA of 92R137 were made with $\mathrm{BAC}$ vector pCC1BAC using the genomic DNA digested separated with HindIII and BamHI. The HindIII construct consisted of 390,144 clones placed in 1,016 384-well plates. From these clones, 453 clones were randomly selected and examined on pulsed-field gels to estimate the insert sizes of the HindIII clones. The HindIII clones were shown to have an average size of $129 \mathrm{~kb}$ and a coverage of 3.01-fold genome of the hexaploid wheat species based on the estimated genome size of $16,700 \mathrm{Mb}$ [36]. The HindIII sublibrary had $1.4 \%$ empty clones (Figures 3 and 4). To estimate the insert size of the $375,552 \mathrm{BamHI}$ clones arrayed in 978 384-well plates,

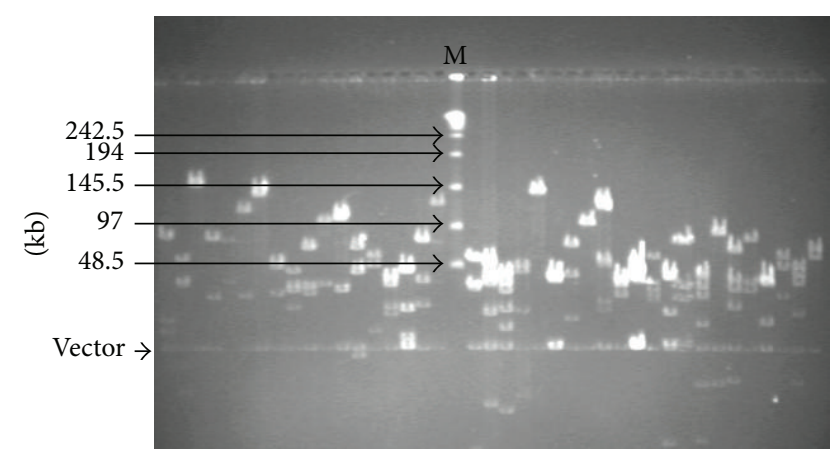

FIGURE 3: NotI digests of plasmids from randomly selected white colonies. The enzyme-digested products of selected plasmids with NotI were loaded onto $1 \%$ agarose in $0.5 x$ TBE CHEF gel, $6 \mathrm{~V} / \mathrm{cm}$, $5-15 \mathrm{~s}$ pulse time for $16 \mathrm{~h}$ at $14^{\circ} \mathrm{C}$. M: the $\lambda$ PFG marker.

573 clones were randomly picked and examined on pulsedfield gels. The BamHI sublibrary had an average clone size of $112.6 \mathrm{~kb}$, representing 2.53-fold coverage of the hexaploid wheat genome, and contained $3.4 \%$ empty clone (Figures 3 and 4). The two sublibraries contained a total of 765,696 clones in 1,994 384-well plates and had an estimated coverage of 5.54-fold genome of hexaploid wheat. All clones were duplicated in 1,994 plates. The probability of identifying a clone containing an interested gene (such as Yr26) from the library was estimated to be $99.6 \%$.

The percentage of contaminated chloroplasts in the library was estimated by screening 846 clones randomly selected with three pairs of primers designed for three chloroplast genes [22]. Among the 846 clones, only 6 were positive for the tested genes, indicating that only $0.71 \%$ of the clones were contaminated by chloroplast genes. 


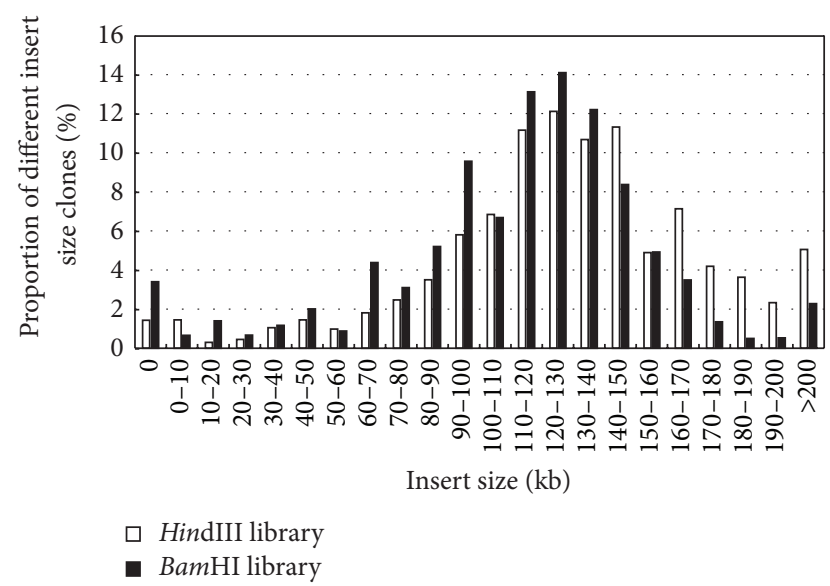

FIGURE 4: Insert size distribution of randomly selected BAC clones including 453 clones constructed with HindIII (open bars) and 573 clones constructed with BamHI (solid bars).

\subsection{BAC Clone Pooling and PCR Screening with Yr26-Linked} Marker. Using the 5D pooling strategy, 400 super-pools (200 RSPs plus 200 CSPs) were constructed. From each super pool, plasmid DNA was extracted and adjusted to $5 \mathrm{ng} / \mu \mathrm{L}$ to be used in the PCR screening for identifying BAC clones containing Xwe173. A total of 400 PCR reactions using the DNA templates from the 400 super-pools were performed three times. The genomic DNA of 92R137 was used as the positive control. Two positive amplifications of Xwe173 were detected in screening the super-pools, and two plates, H186 (constructed with HindIII) and B634 (constructed with BamHI), were identified to contain the marker (Figure 5(a)).

From 40 pools (16 row pools and 24 column pools) constructed from each of the positive plates, two positive amplifications were detected from both column and row pool of clones in plate H186. Similarly, two positive amplifications were detected from the column and three positive amplifications from the row pools of clones from plate B634. Finally, six positive BAC clones (H186H13, H186E15, B634C10, B634C11, B634D10, and B634E10) were identified to contain Xwe173 (Figure 5(b)). The results suggest that the BAC library is suitable for identifying clones contain Yr26 or any other genes in line 92R137.

\section{Discussion}

A large insertion library is the foundation for positional cloning of an interesting gene line Yr26, without reference genome sequences such as $H$. villosa, the donor of Yr26 to hexaploid wheat lines. Because the advantage of easy handling, stability, and low chimerism, the BAC library technique has become relatively popular in modern genetics research compared with other large insert clone techniques [22]. To create such genetic resource for map-based cloning of stripe rust resistance gene Yr26 in wheat line 92R137, a large BAC library consisting of 765,696 clones was constructed by digesting genomic DNA of 92R137 with HindIII and BamHI. The different cloning sites were chosen to enhance unbiased genome representation and minimize the numbers of gaps between $\mathrm{BAC}$ contigs that result from uneven restriction site distributions [39, 42, 43].

Although several BAC libraries are published [22-28], it is still technically required to construct a hexaploid wheat library for interesting genes like Yr26 in a particular wheat genotype. Obtaining high quality DNA fragments of proper sizes is a key step for BAC library construction. Because transformation efficiency and insert size are negatively correlated, small fragments result in remarkably decreased average insert sizes, thereby causing chromosomal walking to become difficult [22]. Although most DNA molecules $<120 \mathrm{~kb}$ are removed by the first size selection, some small DNA fragments are still trapped by larger ones [23, 27]. Many studies confirmed that two size selections could effectively eliminate small restriction fragments, resulting in increased average insert sizes $[26,32,37,44,45]$. Therefore, we conducted the second size selection to eliminate smaller DNA molecules prior to ligation in the present study and proved the effectiveness of the second selection.

After size selection, two major techniques, electroelution and digestion with $\beta$-agarase, are commonly used to recover size-selected DNA from agarose gel. Some previous studies reported that higher transformation efficiencies were achieved with DNAs isolated by electroelution than with $\beta$-agarase $[24,26]$. In electroelution, two electrophoresis buffers, TAE and TBE, are used; however, some researches show that borate contained in TBE can inhibit T4 DNA ligase activity and thus affect cloning and transformation efficiencies $[26,38,46]$. In the present study, we adopted the method of electroelution with TAE buffer and successfully constructed a high quality BAC library.

The ratio of clones contaminated by chloroplasts in the library was estimated to be $0.71 \%$ using the method described by Farrar and Donnison [22]. Compared with those in other BAC libraries for hexaploid wheat, this percentage was slightly higher than those reported by Ratnayaka et al. [34] and Shen et al. [35], but much lower than $2.2 \%$ described by Nilmalgoda et al. [32]. The low percentage of chloroplast clones in the library of our study was achieved mainly with young leaves growing in dark thus reducing their chloroplasts.

Integrating genetic and physical maps is a prerequisite for conducting map-based gene cloning, but the integration needs the essential step of screening a suitable BAC library. The efficiency of BAC library screening can be improved by adopting an appropriate BAC pooling strategy $[47,48]$. The present study fulfilled this requirement by making pools of the clones according to the $5 \mathrm{D}$ clone pooling strategy described by You et al. [40]. Through 400 PCR reactions, 765,696 clones were efficiently tested with the Yr26-linked marker Xwe173. The simple, easy, and high-throughput PCR screening methods for identifying BAC clones are reported in many investigations $[22,32,33,37]$ using different pooling schemes. The implementation of the 5D BAC clone pooling strategy is a highly efficient, low cost, and rapid approach to screen a BAC library. To validate the selected clones, each of them was confirmed through repeated PCR reactions. To achieve specific amplifications, the annealing temperature 


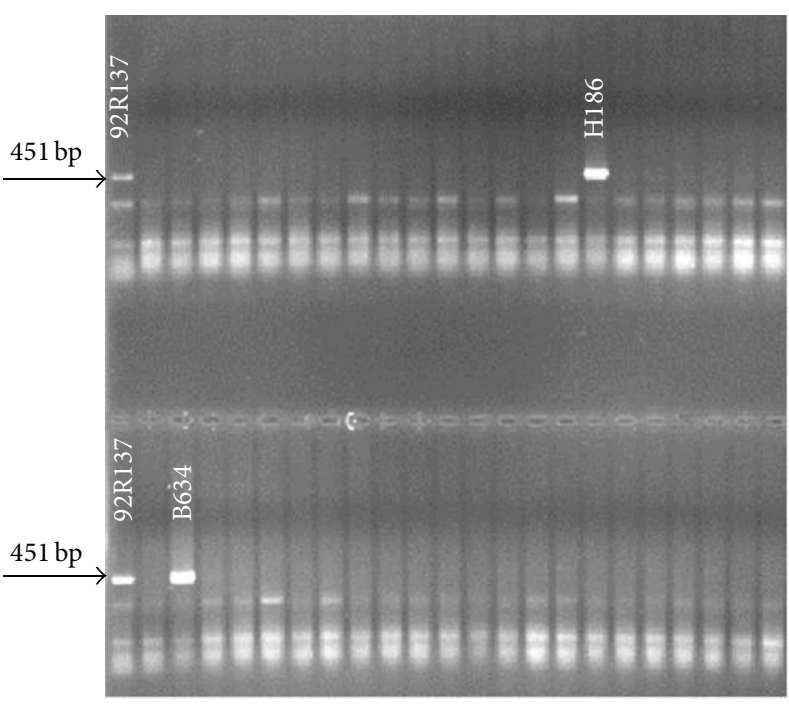

(a)

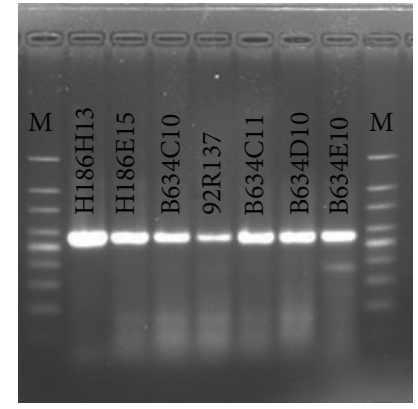

(b)

FIGURE 5: Screening of the BAC library with the Yr26-linked marker Xwe173. (a) Screening of BAC plate pools. A 451-bp band was amplified in positive control 92R137 with Xwe173. Two positive BAC plates, H186 (constructed with HindIII) and B634 (constructed with BamHI), were identified. (b) Six BAC clones (H186H13, H186E15, B634C10, B634C11, B634D10, and B634E10), which were identified from plates H186 and B634, were confirmed to contain Xwe173.

of Xwe173 was increased from $55^{\circ} \mathrm{C}$ to $60^{\circ} \mathrm{C}$ to increase the specificity. At the increased annealing temperatures, six positive BAC clones were identified for the tested marker, proving the suitability of the BAC library for cloning Yr26 and other genes.

Although BAC libraries representing direct diploid sources of wheat A genome (T. monococcum [49], T. urartu, [50], and D genome (T. tauschii) [50]) have been constructed, they cannot be used to clone the stripe rust resistance gene Yr26 because it is located on wheat chromosome $1 \mathrm{~B}[8,10-$ 13]. BAC libraries for tetraploid wheat and hexaploid wheat [29-35] and all chromosome-specific BAC libraries of the hexaploid cultivar Chinese Spring have been developed [37, 45, 51-55], but these BAC libraries are not suitable for cloning Yr26 because the gene is probably derived from T. turgidum $\mathrm{cV} \cdot \gamma 80-1$, the original wheat parent of 92R137 [11]. Therefore, BAC libraries constructed with different cultivars are needed to clone important specific trait genes. Currently, we are using the BAC library constructed in the present study to clone Yr26 to shield light to the molecular mechanisms of stripe rust resistance.

\section{Conflict of Interests}

The authors declare that there is no conflict of interests regarding the publication of this paper.

\section{Acknowledgments}

This study was sponsored by the National Basic Research Program of China (no. 2013CB127700), the National Major Project of Breeding for New Transgenic Organisms in China (2011ZX08002-001), the National Natural Science Foundation of China (31371924), and the 111 Project from the Ministry of Education of China (B07049).

\section{References}

[1] D. Fu, C. Uauy, A. Distelfeld et al., "A kinase-START gene confers temperature-dependent resistance to wheat stripe rust," Science, vol. 323, no. 5919, pp. 1357-1360, 2009.

[2] X.-Q. Huang and M. S. Röder, "Molecular mapping of powdery mildew resistance genes in wheat: a review," Euphytica, vol. 137, no. 2, pp. 203-223, 2004.

[3] D. Sharma-Poudyal, X. Chen, A. Wan et al., "Virulence characterization of international collections of the wheat stripe rust pathogen, Puccinia striiformis f. sp. tritici," Plant Disease, vol. 97, no. 3, pp. 379-386, 2013.

[4] X. M. Chen, "Epidemiology and control of stripe rust [Puccinia striiformis f. sp. tritici] on wheat," Canadian Journal of Plant Pathology, vol. 27, no. 3, pp. 314-337, 2005.

[5] W. Q. Chen, L. R. Wu, T. G. Liu et al., "Race dynamics, diversity, and virulence evolution in Puccinia striiformis f. sp. tritici, the causal agent of wheat stripe rust in china from 2003 to 2007," Plant Disease, vol. 93, no. 11, pp. 1093-1101, 2009.

[6] G. Röbbelen and E. L. Sharp, "Mode of inheritance, interaction and application of genes conditioning resistance to yellow rust," Fortschritte der Pflanzenzuechtung, vol. 9, pp. 1-88, 1978.

[7] R. F. Line and X. Chen, "Successes in breeding for and managing durable resistance to wheat rusts," Plant Disease, vol. 79, no. 12, pp. 1254-1255, 1995.

[8] C. Wang, Y. Zhang, D. Han et al., "SSR and STS markers for wheat stripe rust resistance gene Yr26," Euphytica, vol. 159, no. 3, pp. 359-366, 2008.

[9] A. Cao, L. Xing, X. Wang et al., "Serine/threonine kinase gene $S t p k-V$, a key member of powdery mildew resistance gene Pm21, confers powdery mildew resistance in wheat," Proceedings of the 
National Academy of Sciences of the United States of America, vol. 108, no. 19, pp. 7727-7732, 2011.

[10] G. Q. Li, Z. F. Li, W. Y. Yang et al., "Molecular mapping of stripe rust resistance gene $\mathrm{YrCH} 42$ in Chinese wheat cultivar Chuanmai 42 and its allelism with Yr24 and Yr26," Theoretical and Applied Genetics, vol. 112, no. 8, pp. 1434-1440, 2006.

[11] W. E. Wen, G. Q. Li, Z. H. He, W. Y. Yang, M. L. Xu, and X. C. Xia, "Development of an STS marker tightly linked to Yr26 against wheat stripe rust using the resistance gene-analog polymorphism (RGAP) technique," Molecular Breeding, vol. 22, no. 4, pp. 507-515, 2008.

[12] X. Zhang, D. Han, Q. Zeng et al., "Fine mapping of wheat stripe rust resistance gene Yr26 based on collinearity of wheat with Brachypodium distachyon and rice," PLoS ONE, vol. 8, no. 3, Article ID e57885, 2013.

[13] J. Ma, R. Zhou, Y. Dong, L. Wang, X. Wang, and J. Jia, "Molecular mapping and detection of the yellow rust resistance gene Yr26 in wheat transferred from Triticum turgidum L. using microsatellite markers," Euphytica, vol. 120, no. 2, pp. 219-226, 2001.

[14] T. G. Liu, Y. L. Peng, W. Q. Chen et al., "First detection of virulence in Puccinia striiformis f. sp. tritici in China to resistance genes Yr24 (=Yr26) present in wheat cultivar chuanmai 42," Plant Disease, vol. 94, no. 9, pp. 1163-1163, 2010.

[15] Q.-D. Zeng, D.-J. Han, Q.-L. Wang et al., "Stripe rust resistance and genes in Chinese wheat cultivars and breeding lines," Euphytica, vol. 196, no. 2, pp. 271-284, 2014.

[16] S. Cloutier, B. D. McCallum, C. Loutre et al., "Leaf rust resistance gene Lrl, isolated from bread wheat (Triticum aestivum L.) is a member of the large psr567 gene family," Plant Molecular Biology, vol. 65, no. 1-2, pp. 93-106, 2007.

[17] C. Feuillet, S. Travella, N. Stein, L. Albar, A. Nublat, and B. Keller, "Map-based isolation of the leaf rust disease resistance gene Lr10 from the hexaploid wheat (Triticum aestivum L.) genome," Proceedings of the National Academy of Sciences of the United States of America, vol. 100, no. 25, pp. 15253-15258, 2003.

[18] L. Huang, S. A. Brooks, W. Li, J. P. Fellers, H. N. Trick, and B. S. Gill, "Map-based cloning of leaf rust resistance gene Lr21 from the large and polyploid genome of bread wheat," Genetics, vol. 164, no. 2, pp. 655-664, 2003.

[19] S. Periyannan, J. Moore, M. Ayliffe et al., "The Gene Sr33, an ortholog of barley mla genes, encodes resistance to wheat stem rust race Ug99," Science, vol. 341, no. 6147, pp. 786-788, 2013.

[20] C. Saintenac, W. Zhang, A. Salcedo et al., "Identification of wheat gene $S r 35$ that confers resistance to $U g 99$ stem rust race group," Science, vol. 341, no. 6147, pp. 783-786, 2013.

[21] S. G. Krattinger, E. S. Lagudah, W. Spielmeyer et al., "A putative $\mathrm{ABC}$ transporter confers durable resistance to multiple fungal pathogens in wheat," Science, vol. 323, no. 5919, pp. 1360-1363, 2009.

[22] K. Farrar and I. S. Donnison, "Construction and screening of BAC libraries made from Brachypodium genomic DNA," Nature Protocols, vol. 2, no. 7, pp. 1661-1674, 2007.

[23] H. B. Zhang, X. Zhao, X. Ding, A. H. Paterson, and R. A. Wing, "Preparation of megabase-size DNA from plant nuclei," Plant Journal, vol. 7, no. 1, pp. 175-184, 1995.

[24] S. J. Strong, Y. Ohta, G. W. Litman, and C. T. Amemiya, "Marked improvement of PAC and BAC cloning is achieved using electroelution of pulsed-field gel-separated partial digests of genomic DNA," Nucleic Acids Research, vol. 25, no. 19, pp. 3959-3961, 1997.
[25] R. R. Klein, D. T. Morishige, P. E. Klein, J. Dong, and J. E. Mullet, "High throughput BAC DNA isolation for physical map construction of sorghum (Sorghum bicolor)," Plant Molecular Biology Reporter, vol. 16, no. 4, pp. 351-364, 1998.

[26] K. Osoegawa, P. Y. Woon, B. Zhao et al., "An improved approach for construction of bacterial artificial chromosome libraries," Genomics, vol. 52, no. 1, pp. 1-8, 1998.

[27] D. G. Peterson, J. P. Tomkins, D. A. Frisch et al., "Construction of plant bacterial artificial chromosome (BAC) libraries: an illustrated guide," Journal of Agricultural Genomics, vol. 5, pp. $1-100,2000$.

[28] M. Luo and R. A. Wing, "An improved method for plant BAC library construction," Methods in Molecular Biology, vol. 236, pp. 3-20, 2003.

[29] Z. Ma, S. Weining, P. J. Sharp, and C. Liu, "Non-gridded library: a new approach for BAC (bacterial artificial chromosome) exploitation in hexaploid wheat (Triticum aestivum)," Nucleic Acids Research, vol. 28, no. 24, article E106, 2000.

[30] S. Allouis, G. Moore, A. Bellec et al., "Construction and characterisation of a hexaploid wheat (Triticum aestivum L.) BAC library from the reference germplasm 'Chinese Spring,' Cereal Research Communications, vol. 31, no. 3-4, pp. 331-338, 2003.

[31] A. Cenci, N. Chantret, X. Kong et al., "Construction and characterization of a half million clone BAC library of durum wheat (Triticum turgidum ssp. durum)," Theoretical and Applied Genetics, vol. 107, no. 5, pp. 931-939, 2003.

[32] S. D. Nilmalgoda, S. Cloutier, and A. Z. Walichnowski, "Construction and characterization of a bacterial artificial chromosome (BAC) library of hexaploid wheat (Triticum aestivum L.) and validation of genome coverage using locus-specific primers," Genome, vol. 46, no. 5, pp. 870-878, 2003.

[33] P. Ling and X. M. Chen, "Construction of a hexaploid wheat (Triticum aestivum L.) bacterial artificial chromosome library for cloning genes for stripe rust resistance," Genome, vol. 48, no. 6, pp. 1028-1036, 2005.

[34] I. Ratnayaka, M. Båga, D. B. Fowler, and R. N. Chibbar, "Construction and characterization of a BAC library of a coldtolerant hexaploid wheat cultivar," Crop Science, vol. 45, no. 4, pp. 1571-1577, 2005.

[35] B. Shen, D. M. Wang, C. L. McIntyre, and C. J. Liu, "A "Chinese Spring" wheat (Triticum aestivum L.) bacterial artificial chromosome library and its use in the isolation of SSR markers for targeted genome regions," Theoretical and Applied Genetics, vol. 111, no. 8, pp. 1489-1494, 2005.

[36] M. D. Bennett and I. J. Leitch, "Nuclear DNA amounts in angiosperms," Annals of Botany, vol. 76, no. 2, pp. 113-176, 1995.

[37] H. Šimková, J. Šafář, M. Kubaláková et al., "BAC libraries from wheat chromosome 7D: efficient tool for positional cloning of aphid resistance genes," Journal of Biomedicine and Biotechnology, vol. 2011, Article ID 302543, 11 pages, 2011.

[38] B. J. Shi, T. Sutton, N. C. Collins, M. Pallotta, and P. Langridge, "Construction of a barley bacterial artificial chromosome library suitable for cloning genes for boron tolerance, sodium exclusion and high grain zinc content," Plant Breeding, vol. 129, no. 3, pp. 291-296, 2010.

[39] D. Schulte, R. Ariyadasa, B. Shi et al., "BAC library resources for map-based cloning and physical map construction in barley (Hordeum vulgare L.)," BMC Genomics, vol. 12, article 247, 2011. 
[40] F. M. You, M.-C. Luo, K. Xu, K. R. Deal, O. D. Anderson, and J. Dvorak, "A new implementation of high-throughput fivedimensional clone pooling strategy for BAC library screening," BMC Genomics, vol. 11, no. 1, article 692, 2010.

[41] A. M. Atrazhev and J. F. Elliott, "Simplified desalting of ligation reactions immediately prior to electroporation into E. coli," BioTechniques, vol. 21, no. 6, article 1024, 1996.

[42] Q. Tao, Y.-L. Chang, J. Wang et al., "Bacterial artificial chromosome-based physical map of the rice genome constructed by restriction fingerprint analysis," Genetics, vol. 158, no. 4, pp. 1711-1724, 2001.

[43] N. Huo, Y. Q. Gu, G. R. Lazo et al., "Construction and characterization of two BAC libraries from Brachypodium distachyon, a new model for grass genomics," Genome, vol. 49, no. 9, pp. 1099-1108, 2006.

[44] T. N. Foote, S. Griffiths, S. Allouis, and G. Moore, "Construction and analysis of a BAC library in the grass Brachypodium sylvaticum: its use as a tool to bridge the gap between rice and wheat in elucidating gene content," Functional and Integrative Genomics, vol. 4, no. 1, pp. 26-33, 2004.

[45] J. Šafář, H. Šimková, M. Kubaláková et al., "Generating resources for genomics of wheat homoeologous chromosome group 3: 3AS- and 3DS-specific BAC libraries," Journal of Genetics and Breeding, vol. 61, no. 1-2, pp. 151-160, 2007.

[46] B. Chalhoub, H. Belcram, and M. Caboche, "Efficient cloning of plant genomes into bacterial artificial chromosome (BAC) libraries with larger and more uniform insert size," Plant Biotechnology Journal, vol. 2, no. 3, pp. 181-188, 2004.

[47] E. Barillot, B. Lacroix, and D. Cohen, "Theoretical analysis of library screening using a N-dimensional pooling strategy," Nucleic Acids Research, vol. 19, no. 22, pp. 6241-6247, 1991.

[48] W. J. Bruno, E. Knill, D. J. Balding et al., "Efficient pooling designs for library screening," Genomics, vol. 26, no. 1, pp. 2130, 1995.

[49] D. Lijavetzky, G. Muzzi, T. Wicker, B. Keller, R. Wing, and J. Dubcovsky, "Construction and characterization of a bacterial artificial chromosome (BAC) library for the A genome of wheat," Genome, vol. 42, no. 6, pp. 1176-1182, 1999.

[50] E. D. Akhunov, A. R. Akhunova, and J. Dvořák, "BAC libraries of Triticum urartu, Aegilops speltoides and Ae. tauschii, the diploid ancestors of polyploid wheat," Theoretical and Applied Genetics, vol. 111, no. 8, pp. 1617-1622, 2005.

[51] J. Janda, J. Bartoš, J. Šafář et al., "Construction of a subgenomic BAC library specific for chromosomes 1D, 4D and 6D of hexaploid wheat," Theoretical and Applied Genetics, vol. 109, no. 7, pp. 1337-1345, 2004.

[52] J. Šafář, J. Bartoš, J. Janda et al., "Dissecting large and complex genomes: flow sorting and BAC cloning of individual chromosomes from bread wheat," Plant Journal, vol. 39, no. 6, pp. 960968, 2004.

[53] J. Janda, J. Šafáŕ, M. Kubaláková et al., "Advanced resources for plant genomics: a BAC library specific for the short arm of wheat chromosome 1B," Plant Journal, vol. 47, no. 6, pp. 977986, 2006.

[54] E. Paux, D. Roger, E. Badaeva et al., "Characterizing the composition and evolution of homoeologous genomes in hexaploid wheat through BAC-end sequencing on chromosome 3B," Plant Journal, vol. 48, no. 3, pp. 463-474, 2006.

[55] J. Šafáŕ, H. Šimková, M. Kubaláková et al., "Development of chromosome-specific BAC resources for genomics of bread wheat," Cytogenetic and Genome Research, vol. 129, no. 1-3, pp. 211-223, 2010. 

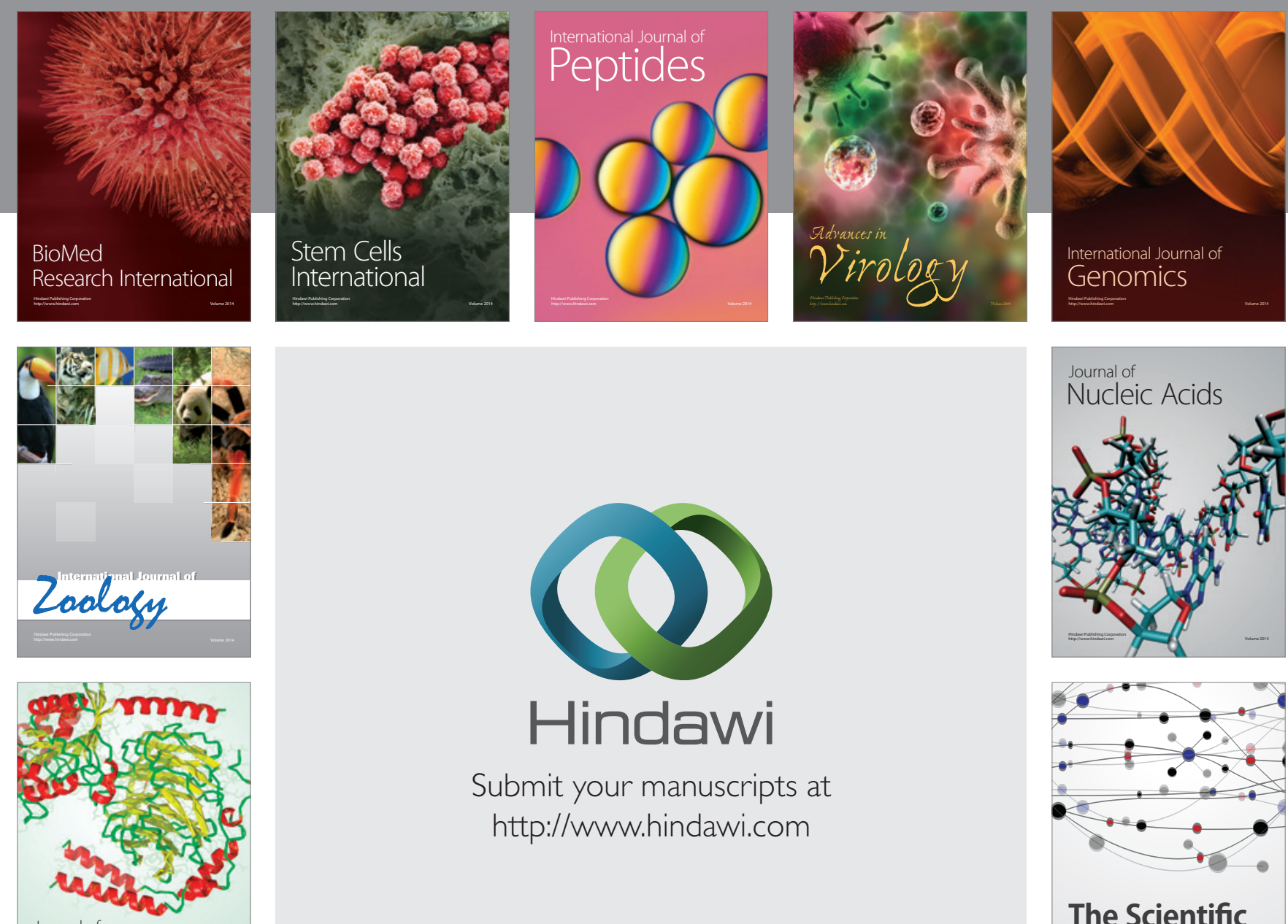

Submit your manuscripts at

http://www.hindawi.com

Journal of
Signal Transduction
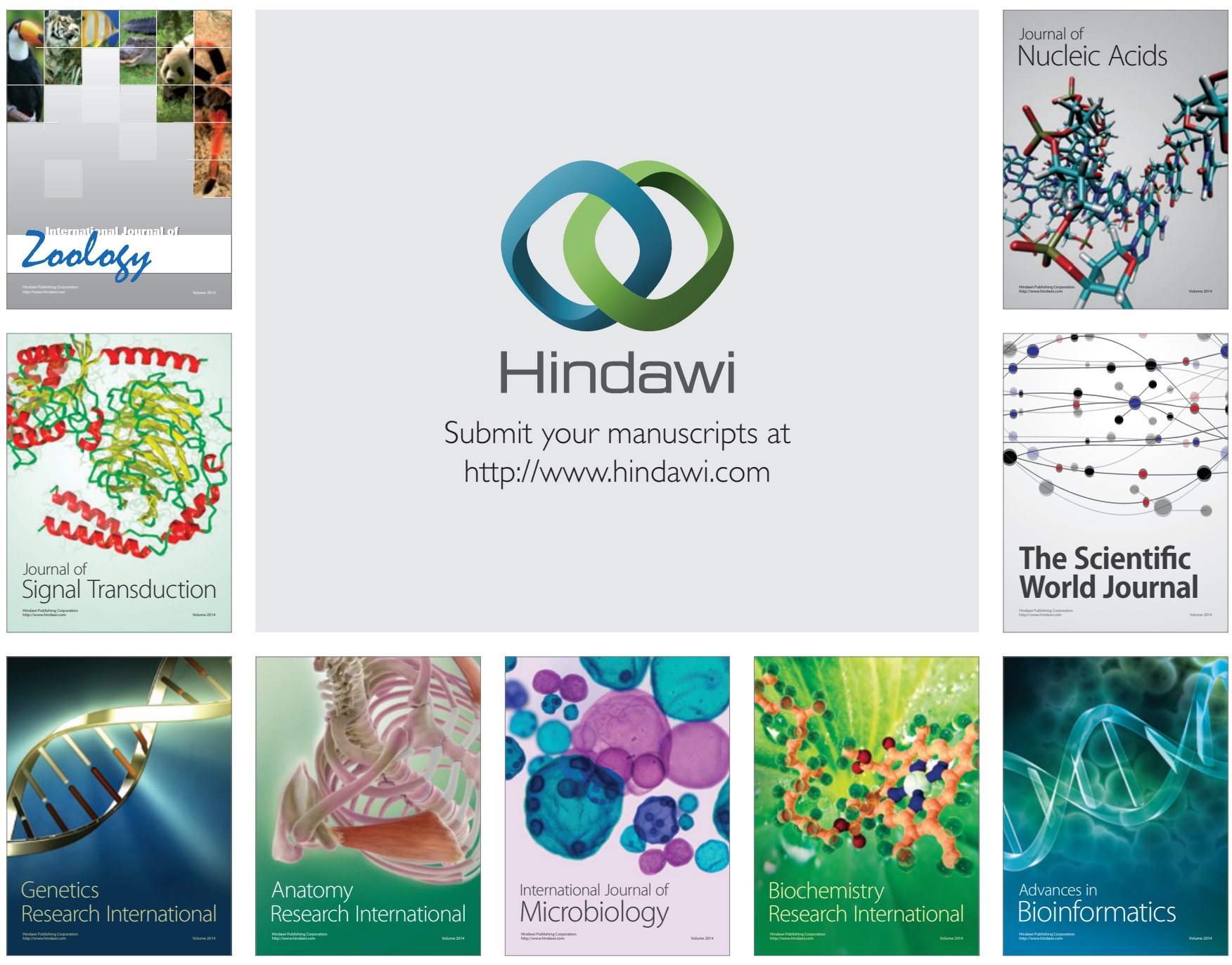

The Scientific World Journal
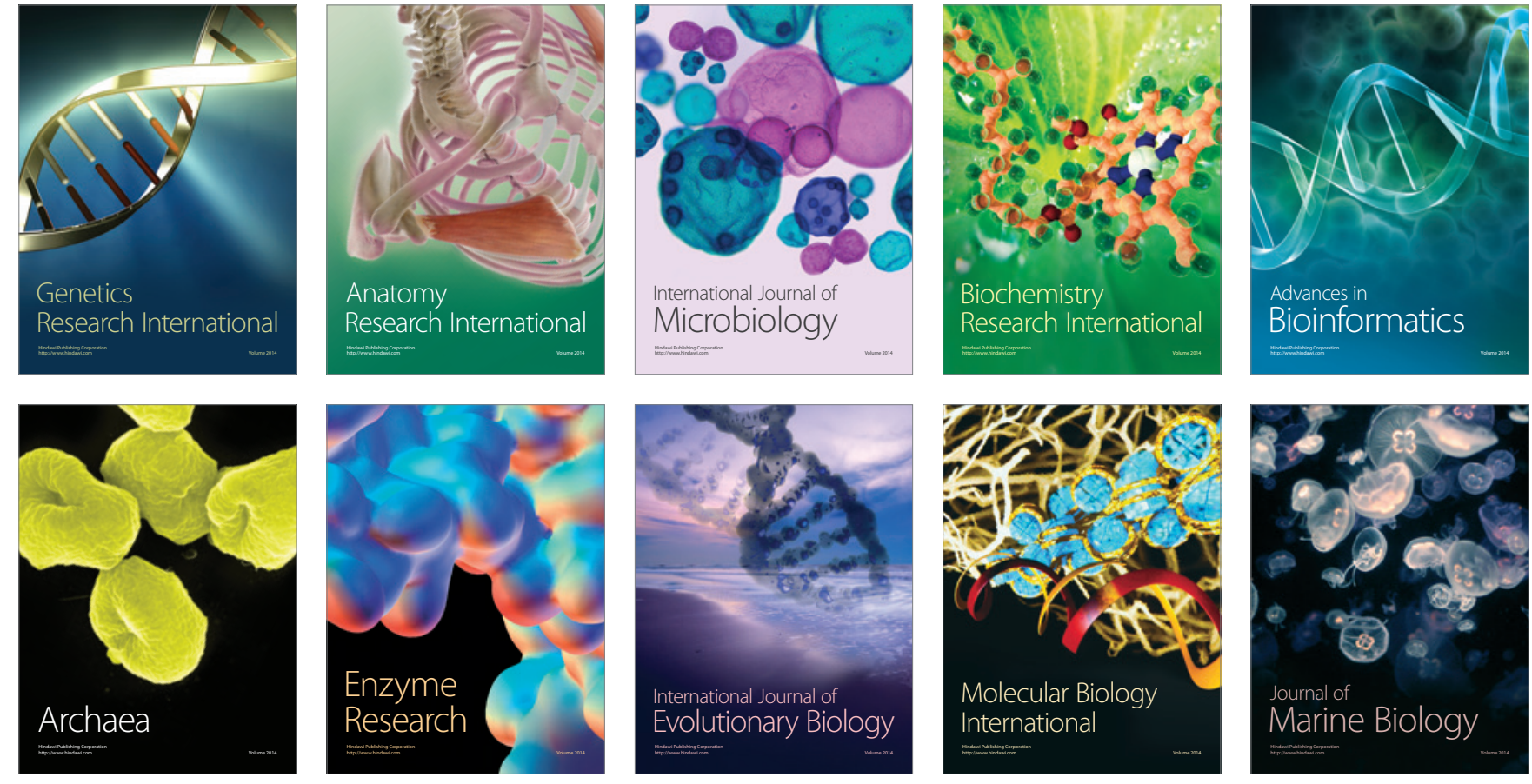